\title{
International Code of Nomenclature of Prokaryotes. Appendix 9: Orthography
}

\author{
Correspondence \\ Hans G. Trüper \\ hgtrueper@googlemail.com \\ Jean P. Euzéby \\ email address can be found at \\ www.bacterio.net
}

\author{
Hans G. Trüper ${ }^{1}$ and Jean P. Euzéby ${ }^{2}$ \\ ${ }^{1}$ Institut für Mikrobiologie \& Biotechnologie, Rheinische Friedrich-Wilhelms-Universität, \\ Meckenheimer Allee 168, D-53115 Bonn, Germany \\ ${ }^{2}$ Société de Bactériologie Systématique et Vétérinaire (SBSV) and École Nationale Vétérinaire de \\ Toulouse (ENVT), BP 87614, F-31076 Toulouse cedex 3, France
}

\section{Preamble}

When naming an organism, authors should be aware of the fact that there is no guarantee that all strains of a newly named species or all species of a newly named genus possess the property or properties used for the formation of that name.

\section{A. Formation of Compound Names}

(1) Compound names are formed by combining two or more words or word elements of Latin and/or Greek origin into one generic name or specific epithet. In most cases two word elements are used (e.g. Thio/bacillus, thio/parus), but up to four elements may be found (e.g. Ectolthiolrhodol spira). The combination of word elements follows four basic rules:

(a) Except for the last word element only the word stems are to be used.

(b) The connecting vowel is -o- when the preceding word element is of Greek origin, it is - $\mathrm{i}$ - when the preceding word element is of Latin origin. Greek is more flexible than Latin about the connecting vowel, and other connecting vowels than -o- may be used if a precedent is found in Greek. Example: Corynebacterium.

(c) A connecting vowel is dropped when the following word element starts with a vowel.

(d) Hyphens and diacritic signs are not allowed (see Rules $12 \mathrm{a}$ and 64 , respectively).

(2) Exemptions from these regulations exist only for the following cases:

(a) When well-established word elements from chemistry or physics are used, their use in these sciences

Conceived and written on behalf of the Judicial Commission (JC) of the International Committee on Systematics of Prokaryotes (ICSP). Accepted at the Plenary Meetings of the JC and the ICSP during the IUMS Congress in San Francisco, CA, USA, 23-29 July 2005.

'The Code' should be taken to refer throughout to the International Code of Nomenclature of Prokaryotes. must be followed. Examples: thio- for sulfur does not lose the -o- in combinations such as Thioalkalibacter and thiooxidans (following the usage in chemistry: thioether, thioester); likewise radio- would not lose the - $\mathrm{O}$ - in combinations such as 'Radioalkalibacter' or 'radioegens' (following the usage in physics: radioactive).

(b) As in inorganic chemistry the vowels $-\mathrm{o}$ and $-\mathrm{i}$ are used to indicate different oxidation levels of cations (e.g. ferro, ferri, cupro, cupri, etc.); they do not fall under the Greek/Latin ruling for connection vowels when used in prokaryote names. Examples: Ferroglobus is an $\mathrm{Fe}^{2+}$ oxidizer, while Ferrimonas is an $\mathrm{Fe}^{3+}$ reducer.

(c) In word components like bio-, geo-, halo-, neo-, macro-, micro-, etc., the connecting vowel -o- may be kept when a component follows that begins with a vowel (for reasons of clarity or of previous usage).

\section{B. Generic (and subgeneric) names}

(1) The name of a genus (or subgenus) is a Latin noun (substantive) in the nominative case. If adjectives or participles are chosen to form generic names they have to be transformed into substantives (nouns) and handled as such. In some cases the substantivation has already happened in classical Latin (e.g. Serpens).

Examples:

(a) genuine nouns: Bacillus, Streptococcus, Escherichia, Azotobacter;

(b) substantivated adjectives: Ammoniphilus, Halorubrum, Methanosalsum, Rubritepida;

(c) substantivated participles of the present: Agarivorans, Myceligenerans, Serpens;

(d) substantivated participles of the perfect: Amycolata, Aquiflexum, Gemmata, Microlunatus, Pectinatus.

(2) Both Latin and Greek know three genders, i.e. contain nouns of masculine, feminine and neuter gender. Adjectives associated with nouns follow these in gender. For the correct formation of specific epithets (as adjectives) 
it is therefore necessary to know the gender of the genus name or of its last component, as appropriate.

Examples for some last components in compound generic names are:

of masculine gender: -arcus, -bacillus, -bacter, -coccus, -ger, -globus, -myces, -philus, -planes, -sinus and -vibrio;

of feminine gender: -arcula, -cystis, -ella, -ia, -illa, -ina, - musa, -monas, -opsis, -phaga, -pila, -rhabdus, -sarcina, -sphaera, -spira, -spina, -spora, -thrix and -toga; of feminine or masculine gender: -cola (-incola); of neuter gender: -bacterium,-bactrum, -baculum, -filamentum, -filum, -genium, -microbium, -nema, -plasma, -spirillum, -sporangium and -tomaculum; of masculine or feminine or neuter gender:-ferax, $-f e x$ and -vorax.

(3) The gender of a new genus must be indicated with the etymology given in the description.

\section{Specific (and subspecific) epithets}

(1) Rule $12 \mathrm{c}$ of the Code demands that specific (or subspecific) epithets must be treated in one of the three following ways:

(a) as an adjective that must agree in gender with the generic name;

(b) as a substantive (noun) in apposition in the nominative case;

(c) as a substantive (noun) in the genitive case.

Examples: (a) Staphylococcus aureus (adjective: 'golden'), (b) Desulfovibrio gigas (nominative noun: 'the giant'), (c) Escherichia coli (genitive noun: 'of the colum=colon').

\section{(2) Adjectives and participles as specific epithets}

(a) Latin adjectives belong to the 1st, 2nd or 3rd declension. Those of the 1st and 2nd declension have different endings in the three genders. In the $3 \mathrm{rd}$ declension the situation is more complicated, as there are adjectives that don't change with gender, others that do and some that are identical in the masculine and feminine gender and different in the neuter.

Table 1 gives some examples. Note that comparative adjectives are also listed. It is recommended always to look up an adjective in a dictionary before using it for the formation of a name.

(b) Participles are treated as if they are adjectives, i.e. they fall under Rule 12c (2) of the Code.

(c) Infinitive (also named 'present') participles in the singular do not change with gender. According to the four conjugations of Latin they end in -ans (first conjugation, e.g. vorans devouring, from vorare to devour, voro I devour), -ens (second conjugation, e.g. inhibens inhibiting, from inhibere to inhibit, inhibeo I inhibit), -ens (third
Table 1. Examples of Latin adjectives

\begin{tabular}{|llll|}
\hline Masculine & Feminine & Neuter & $\begin{array}{c}\text { English } \\
\text { translation }\end{array}$ \\
\hline $\begin{array}{l}\text { 1st and 2nd declension } \\
\text { bonus }^{*}\end{array}$ & bona & bonum & good \\
aureus & aurea & aureum & golden \\
miser & misera & miserum & wretched \\
piger & pigra & pigrum & fat, lazy \\
ruber & rubra & rubrum & red \\
pulcher & pulchra & pulchrum & beautiful \\
3rd declension & putris & putre & rotten \\
puter & celeris & celere & rapid \\
celer & facilis & facile & easy \\
facilis & facilior & facilius & easier \\
facilior & maior & maius & more \\
maior & minor & minus & less \\
minor & simplex & simplex & simple \\
simplex & egens & egens & needy \\
egens $\dagger$ & & & \\
\hline
\end{tabular}

${ }^{\star}$ Most common types.

$\dagger$ Infinitive participle used as adjective.

conjugation, e.g. exigens demanding, from exigere to demand, exigo I demand), -iens (third conjugation, e.g. faciens making, from facere to make, facio, I make), -iens (fourth conjugation, e.g. oboediens obeying, from oboedire to obey, oboedio I obey). Note that knowledge of the ending of the first person singular in the present is decisive!

(d) Perfect participles change their endings with gender and are handled like adjectives of the first and second declension, e.g. aggregatus (masc.), aggregata (fem.), aggregatum (neut.) (aggregated, from aggregare to get together), flexus, flexa, flexum (bent, from flectere to bend), latus, lata, latum (carried, from the irregular verb ferre to carry), diminutus, diminuta, diminutum (smashed, from diminuere to smash).

\section{(3) Nominative nouns in apposition as specific epithets}

(a) Nominative nouns in apposition must make sense to be acceptable. In grammar, apposition means 'the placing of a word or expression beside another so that the second explains and has the same grammatical construction as the first'; i.e. the added nominative noun has an explanatory specifying function for the generic name, thus, e.g. Desulfovibrio gigas may be understood as Desulfovibrio dictus gigas and translated as 'Desulfovibrio, called the giant', which, with reference to the unusual cell size of this species, makes sense.

(b) All specific epithets ending with the Latin suffixes - cola (derived from incola, 'the inhabitant, dweller') and -cida ('the killer') fulfil the above-mentioned requirement. 


\section{(4) Genitive nouns as specific epithets}

(a) The formation of specific epithets as genitive nouns does not pose problems, as the singular genitive of substantives (nouns) is usually given in dictionaries.

(b) If the plural genitive is preferred, as for example in Lactobacillus plantarum ('of plants'), one has to find out the declension of the noun, as plural genitives are different in different declensions [see F (3)]. Examples: Curtobacterium plantarum (first declension), Staphylococcus equorum (second declension), Bifidobacterium dentium (third declension); examples not yet found of the fourth and fifth declensions.

\section{Formation of prokaryote names from personal names}

(1) Persons may be honoured by using their name in forming a generic name or a specific epithet. The Code, however, strongly recommends refraining from naming genera (and subgenera) after persons that are not connected with bacteriology or at least with natural science (Recommendation 10a) and, in the case of specific epithets, to ensure that, if taken from the name of a person, it recalls the name of one who discovered or described it, or was in some way connected with it (Recommendation 12c).

(2) It is good practice to ask the person to be honoured by a scientific name for permission (as long as she/he is alive). Authors should refrain from naming bacteria after themselves or co-authors after each other in the same publication, as this is considered immodest by the majority of the scientific community [see Recommendation 6 (10)].

\section{(3) Personal names in generic names}

(a) The Code provides two ways to form a generic name from a personal name: either directly by adding the ending -a, -ea, -nia or -ia or as a diminutive by adding, usually, the ending -ella, -iella or -nella. Both kinds are always in the feminine gender. Examples are provided in Table 2.

(b) Some personal names in Europe were already Latinized before 1800 and kept since. If they end in -us, replace the ending by -a or -ella (diminutive) respectively (e.g. the name Bucerius would result in 'Buceria' or 'Buceriella'). Beware, however, of Lithuanian names like Didlaukus, Zeikus, etc.! These are not Latinized but genuine forms and would receive the ending -ia according to Table 2.

(c) Not more than one person can be honoured in one generic name or epithet.

(d) If an organism is named after a person, the name cannot be shortened, e.g. 'Wigglesia' after Wigglesworth, 'Stackia' after Stackebrandt or 'Goodfellia' after Goodfellow, etc., but must appear fully.

Personal titles (Sir, Lord, Duke, Baron, Graf, Conte, etc.) are not included in prokaryote names, although they may belong to the name according to the laws of the respective country. Prefixes and particles should be treated as follows:

The Scottish patronymic prefixes 'Mac', 'Mc' and ' $M$ ', meaning 'son of', should be written 'mac' and be united with the rest of the name (e.g. 'Macdonellia' or 'macdonellii' after MacDonell; Macginleya or macginleyi after McGinley).

The Irish patronymic prefix 'O' should be united with the rest of the name or omitted (e.g.

Table 2. Ways to form generic names from personal names

Some names may be hypothetical examples.

\begin{tabular}{|c|c|c|c|c|c|}
\hline Personal name ending in & Person & Add ending & Example & Diminutive ending & Example \\
\hline \multirow[t]{2}{*}{-e } & Benecke & $-\mathrm{a}$ & Beneckea & $-11 \mathrm{a}$ & Beneckella \\
\hline & Burke & -ia & Burkeia & $-1 l a$ & Burkella \\
\hline$-\mathrm{i}$ & Nevski & $-\mathrm{a}$ & Nevskia & -ella & Nevskiella \\
\hline$-\mathrm{u}$ & Manescu & $-\mathrm{ia}$ & Manescuia & -ella & Manescuella \\
\hline$-y$ & Deley & $-\mathrm{a}$ & Deleya & -ella & Deleyella \\
\hline \multirow[t]{2}{*}{-er } & Buchner & $-\mathrm{a}$ & Buchnera & -ella & Buchnerella \\
\hline & Lister & -ia & Listeria & -iella & Listeriella \\
\hline Any consonant & Cabot & $-\mathrm{ia}$ & Cabotia & -(i)ella & Cabot(i)ella \\
\hline
\end{tabular}

${ }^{\star}$ This name of Lithuanian origin is not a genuine Latinized name. If it were, the genus names 'Zeikia' or 'Zeik(i)ella' might have been possible. 
'Oconnoria' or 'Connoria' or 'oconnorii' or 'connorii' after O'Connor).

A prefix consisting of an article (e.g. le, la, l', les, el, il, lo, de), or containing an article (e.g. du, de la, des, del, della, do, da), may be omitted or united to the name (e.g. Rochalimaea after da Rocha-Lima; Leclercia or 'leclercii' after Le Clerc; Leminorella or leminorii after Le Minor; 'Loprestia' or 'loprestii' after Lo Presti, Deleya or deleyi after de Ley, Devosia or 'devosii' after De Vos).

The Dutch prefix 'van' and the German prefix 'von' may be omitted or united to the name (e.g. Escherichia after von Escherich; Leeuwenhoekia after van Leeuwenhoek, itersonii after van Iterson, prowazekii after von Prowazek, 'Vannielia' or vannielii after van Niel; 'Vandertoornia' or 'vandertoornii' or 'Toornia' or 'toornii' after van der Toorn, 'Vandammella' or 'vandammei' after Vandamme).

The adjective Saint (San, Sankt, Santo, -a, Sveti, etc.) as part of some family names may be omitted or united to the name (e.g. 'Exuperya' or 'exuperyi' after Saint-Exupéry, 'Sanmartinia' or 'sanmartinii' after San Martin).

(e) Rarely, generic names or specific epithets have been formed from forenames (first names, given names, Christian names), i.e. not from the family name. Examples: Erwinia was named after Erwin F. Smith; the first name Arletta appears in Staphylococcus arlettae (N.L. gen. n. arlettae of Arletta, named after Arlette van de Kerckhove). First names may be chosen in order to avoid rather long family names or unusually long (hyphenated) double names.

(f) In cases of very frequent family names where the honoured person is not easily identifiable, first and family name may be contracted without connecting vowel or hyphenation, but otherwise treated like a single family name. Examples: Owenweeksia, Elizabethkingia.

\section{(4) Personal names in specific epithets}

(a) To form specific epithets from personal names there are principally two possibilities: the adjective form and the genitive noun form. The adjective form has no means to recognize the sex of the honoured person, which, in principle, is not necessary for nomenclatural purposes. The personal names receive appropriate endings according to the gender of the generic name as indicated in Table 3 . Thus an adjective epithet is formed that has the meaning of 'pertaining/relating/belonging to ... (the person)'.

(b) When the genitive of a Latinized personal name is formed for a specific epithet, the sex of the person to be honoured may be taken into consideration as indicated in Table 4.

On the basis of classical, medieval and Neo-Latin usage, any of the forms of Latinization listed in Table 4 may be chosen. As evident from Table 4, the formation of specific
Table 3. Formation of specific epithets from personal names in the adjective form

Some names may be hypothetical examples.

\begin{tabular}{|llccc|}
\hline $\begin{array}{l}\text { Ending of } \\
\text { name }\end{array}$ & $\begin{array}{c}\text { Example } \\
\text { family name }\end{array}$ & \multicolumn{3}{c|}{$\begin{array}{c}\text { Add the endings } \\
\text { for gender }\end{array}$} \\
\cline { 3 - 5 } & & Masculine & Feminine & Neuter \\
\hline consonant & Grant & -ianus & -iana & -ianum \\
-a & Kondratieva & -nus & -na & -num \\
$-\mathrm{e}$ & Lee & -anus & -ana & -anum \\
$-\mathrm{i}$ & Bianchi & -anus & -ana & -anum \\
$-\mathrm{o}$ & Guerrero & -anus & -ana & -anum \\
$-\mathrm{u}$ & Manescu & -anus & -ana & -anum \\
$-\mathrm{y}$ & Bergey & -anus & -ana & -anum \\
\hline
\end{tabular}

epithets from personal names as genitive nouns poses certain problems only with names ending in -a and -o.

(c) The recommendations and rules for genus names as given above [D (3), (c)-(f)] are also applicable for specific epithets. Appropriate examples are given there.

\section{E. Formation of prokaryote names from geographical names}

(1) The formation of prokaryote names from geographical names has no geopolitical meaning, i.e. such names cannot be used to express geopolitical claims.

(2) Unlike epithets derived from personal names, epithets on the basis of geographical names cannot be formed as substantives in the genitive case. They must be adjectives and are usually constructed by adding the ending -ensis (masculine or feminine gender) or -ense (neuter gender) to the geographical name in agreement with the latter's gender. Only if the name of the locality ends in -a or -e or -en, these letters are dropped before adding -ensis/-ense (e.g. jenensis from Jena, californiensis from California, drentensis from Drente, bremensis from Bremen). If the locality's name ends in -o, the ending becomes -nensis/ -nense (e.g. the name of the Japanese city Sapporo: sapporonensis, sapporonense).

(3) Quite a number of localities in the Old World (Europe, Asia, Africa) have classical Greek, Latin or medieval Latin names and adjectives derived from these: aegyptius (Egypt), africanus (Africa), arabicus (Arabia), asiaticus (Asia), balticus (Baltic Sea), bavaricus (Bavaria), bretonicus (Brittany), britannicus (Britain), europaeus (Europe), frisius (Friesland), gallicus (France), germanicus (Germany), graecus (Greece), hellenicus (Hellas, classical Greece), helveticus (Switzerland), hibernicus (Ireland), hispanicus (Spain), hungaricus (Hungary), ibericus (Spain/Portugal, the Iberian peninsula), indicus (India), italicus (Italy), mediterraneus (Mediterranean Sea), persicus (Persia, Iran), polonus (Poland), rhenanus (Rhineland), romanus (Rome), 
Table 4. Formation of specific epithets from personal names as genitive nouns

Some names may be hypothetical examples.

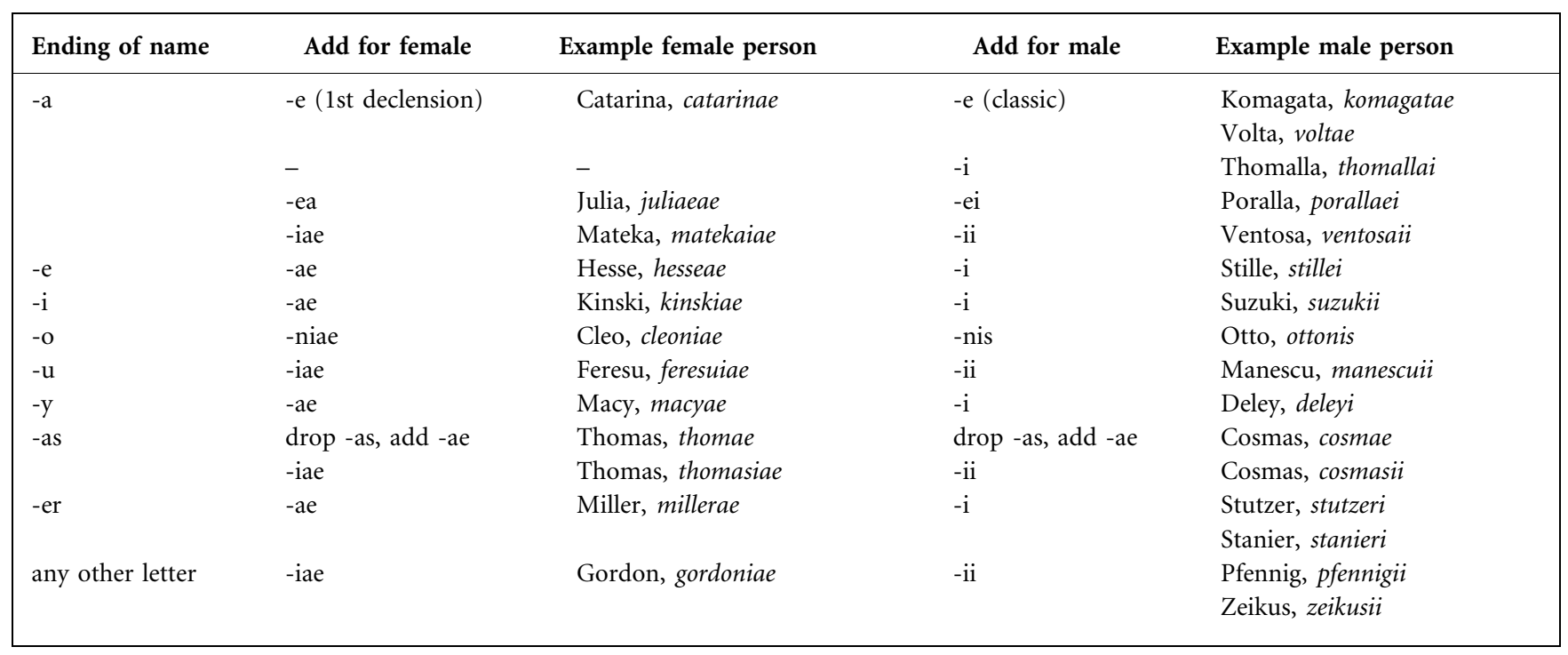

saxonicus (Saxony), etc. Later, Neo-Latin names were also given to many other non-European parts of the world, so adjectives like americanus (America), antarcticus (Antarctica), australicus (Australia), cubanus (Cuba), mexicanus (Mexico), japonicus (Japan), etc. were introduced. Wherever such older adjectives exist they may be used as specific epithets to indicate geographical origins.

(4) European and Mediterranean cities and places of classical times may have had quite different names than today, e.g. Lucentum (Alicante, Spain), Argentoratum (Strasbourg, France), Lutetia (Paris, France), Traiectum (Utrecht, Netherlands), Ratisbona (Regensburg, Germany), Eboracum (York, UK), Londinium (London, UK) and Hafnia (København, Denmark), which lead to the respective adjectives lucentensis, argentoratensis, lutetiensis, traiectensis, ratisbonensis, eboracensis, londiniensis and hafniensis but, alternatively, the Neo-Latin adjectives of the modern names may also be used: alicantensis, strasbourgensis, parisensis, utrechtensis, regensburgensis, yorkensis, londonensis, kobenhavnensis, respectively.

(5) Many localities (mostly lakes, rivers, seas, islands, capes, rocks, mountains or valleys, but also some cities and towns) have names that consist of two words, usually an adjective and a substantive (noun) (e.g. Deep Lake, Black Sea, Red River, Rio Grande, Long Island, Blue Mountain, Baton Rouge, Santa Cruz, Saint Germain, Sankt Georgen, etc.) or two substantives (e.g. Death Valley, Lake Windermere, Loch Ness, Martha's Vineyard, Ayers Rock, Woods Hole, Cape Cod, Monte Carlo, etc.). The formation of specific epithets from such localities' names may pose a problem, as the use of the adjectival suffix -ensis, -ense may lead to rather strange looking or awkward constructions, such as 'deeplakensis' or 'bluemountainense', although they would be formally correct. If a name of a locality lends itself to translation into Latin, specific epithets may as well be formed as genitive substantives of the two components and concatenating them without hyphenation, like the existing ones lacusprofundi (of Deep Lake), marisnigri (of the Black Sea), marismortui (of the Dead Sea) or, of two nouns, vallismortis (of Death Valley). Note that in Latin the basic noun comes first, the determining word (adjective or noun) second!

(6) The inclusion of articles (such as the, el, o, il, le, la, a, de, der, die, das, den, het or their plurals the, los, las, os, as, les, $i l s, g l i, l e, d e, d i e, s$, etc.) as they are used for locations in several languages (e.g. La Paz, El Ferrol, El Alamein, Le Havre, The Netherlands, Die Schweiz, Den Haag, s'Hertogenbosch, Los Angeles, etc.) should be avoided. Articles would unnecessarily elongate names without adding information.

\section{F. Formation of names for prokaryotes living in association or symbiosis with other biota}

(1) For the formation of names for prokaryotes that live in association or symbiosis with plants, fungi, animals or other prokaryotes it is important to know the exact meaning of the nomenclatural name of such a partner and how it was formed (adjective, genitive noun, etc.).

(2) The easiest way of forming such specific epithets is the use of the genitive case of the generic name of the associated organism in question, e.g. suis, equi, bovis, muscae, muris, aquilae, falconis, gypis, elephantis (of the pig, horse, cow, fly, mouse, eagle, falcon, vulture, elephant), or fagi, quercus (4th declension genitive, spoken with long $\mathrm{u}$ ), castaneae, aesculi, rosae, liliae (of the beech, oak, chestnut, horse chestnut, rose, lily). 
(3) Alternatively the genitive of the plural is recommendable, especially if several species of the associated (usually) eukaryotic genus house the prokaryote species in question. To form the plural genitive one needs to know the stem and declension of the word.

The following examples may be of some assistance:

(i) 1st declension: -arum (muscarum, of flies, rosarum, of roses);

(ii) 2nd declension: -orum (equorum, of horses, pinorum, of pines);

(iii) 3rd declension (consonant stems): -um (leonum, of lions, leguminum, of legumes);

(iv) 3rd declension (vocal and mixed stems): -ium (felium, of cats, ruminantium, of ruminants);

(v) 4th declension: -um (quercum, of oaks);

(vi) 5th declension: -rum (scabierum, of different forms of scabies, a skin desease).

Be aware of irregular forms such as bos (the cow), genitive bovis, plural genitive boum; canis (the dog), genitive canis, plural genitive canum! Use dictionaries!

\section{G. Names originating from languages other than Latin or Greek}

(1) As the Code defined Latin or, better, Neo-Latin as the language of prokaryote nomenclature, names should not be taken from other languages as long as they may be constructed from Latin or Greek word stems [Recommendation 6 (3)]. Only Latin gender endings are permitted. Greek endings must be transformed into Latin endings. Example: The formation of the epithet simbae from the East African Swahili word simba, lion, for a Mycoplasma species was not necessary because in this genus the corresponding Latin epithet leonis (of the lion) had not been used before.

(2) When it becomes unavoidable to use a word from another language the word stem must be identified before Latinization. Example: the Arabic word 'alkali' (al-qaliy, the ashes of saltwort) from which the element kalium (K; English, potassium) received its name. As the $-i$ at the end of the word belongs to the stem it is wrong to speak and write of alcalophilic instead of alkaliphilic microbes.

(3) Typical usages of the other language should not be carried over into Latin. Example: the English suffix -philic (e.g. hydrophilic: friendly to water, water-loving) is an English transformation of the Latin -philus, $-a,-u m$ (originating from Greek philos, friendly). Therefore the ending -philicus must be avoided and -philus be used instead.

(4) National foods or fermentation products (e.g. sake, tofu, miso, yogurt, kvas, kefir, pombe, pulque, aiva, etc.) often do not have equivalent Latin names and if typical micro-organisms found in them or causing their fermentations are described, they may be named after them. These names cannot be used unaltered just as specific epithets in the form of nominative substantives in apposition. They are properly Latinized by forming a neuter substantive from them by adding -um (e.g. sakeum, tofuum, kefirum, pombeum, etc.) and the use of the genitive of that (ending i) in the specific epithet (e.g. sakei, tofui, kefiri, pombei, etc.).

\section{H. Formation of prokaryote names from names of elements and compounds used in chemistry and pharmacy}

(1) The vast majority of names of chemicals are Latinized as neuter nouns of the 2nd declension with nominatives ending -um, genitives in - $i$. The following groups belong in this category:

(a) Most of the chemical elements with the exception of carbon (L. carbo, carbonis) phosphorus (L. phosphorus, phosphori) and sulfur (L. sulfur, sulfuris) have the ending -(i)um with the genitive ending in $-(i) i$; nitrogen may also be called azotum besides nitrogenium, calcium may also be called calx (genitive calcis).

(b) Names of chemical and biochemical compounds ending in -ide (including anions), -in, -ane, -ene, -one, -ol (only non-alcoholic compounds), -ose (sugars), -an (polysaccharides) and -ase (enzymes) are Latinized by adding the ending $-u m$ or by replacing the $-e$ at the end by $-u m$ as appropriate.

(c) Acids are named by acidum (L. neuter noun, acid), followed by a descriptive neuter adjective, e.g. sulfurous acid acidum sulfurosum, sulfuric acid acidum sulfuricum, acetic acid acidum aceticum.

(2) The second largest category of chemicals are treated as neuter nouns of the 3rd declension: These are those ending in -ol (the alcohols), - al (aldehydes), - er (ethers, esters) and $-y l$ (organic radicals); Latinization does not change their names at the end, whereas the genitive is formed by adding -is.

(3) Anions ending in -ite and -ate are treated as masculine nouns of the 3rd declension. The English ending -ite is Latinized to - $i s$, with the genitive -itis, e.g. nitrite becomes nitris, nitritis. The English ending -ate is Latinized to -as, with the genitive -atis, e.g. nitrate becomes nitras, nitratis.

(4) Only a few chemicals have names that are Latinized in the 1 st declension as feminine nouns, ending in $-a$ with a genitive in $-a e$. Besides chemicals that always had names ending in $-a$ (like urea), these are drugs found in classical and medieval Latin, such as gentian (gentiana) and camphor (camphora), and further modern drugs, whose Latin names were formed by adding - $a$, like the French ergot becoming ergota in Latin. An important group of this category are alkaloids and other organic bases, such as nucleic acid bases and amino acids with English names ending in -ine. In Neo-Latin this ending is -ina, with the genitive -inae. Examples: betaina, -ae; atropina, -ae; adenina, -ae; alanina, -ae, etc. 
(5) Names of pharmaceutical and chemical products or their registered or unregistered trade names are Latinized following the instructions given above.

(6) For their use in prokaryote generic names and specific epithets, word stems and genitives of Latinized chemical names are the basis. In principle they are then treated like any other word elements.

\section{Arbitrary names}

(1) The bases for arbitrary names are Rules 10a and 12c of the Code: 'genus names or specific epithets may be taken from any source and may even be composed in an arbitrary manner'. They must, however, be treated as Latin. Often they are vocalized abbreviations or contractions of names.

Examples: Cedecea, Afipia, Kordia, Kribbella, Waddlia and Desemzia, that were derived from the acronyms CDC (Centers for Disease Control), AFIP (Armed Forces Institute of Pathology), KORDI (Korea Ocean Research and Development Institute), KRIBB (Korean Research Institute of Bioscience and Biotechnology), WADDL (Washington Animal Disease Diagnostic Laboratory) and DSMZ (Deutsche Sammlung von Mikroorganismen und Zellkulturen), respectively. Another example is Simkania (contracted from the name Simona Kahane). Examples for arbitrary specific epithets are (Burkholderia) unamae, derived from the acronym UNAM (Universidad Nacional Autonóma de México), (Brevundimonas) nasdae, derived from the acronym NASDA (National Space Development Agency of Japan), and (Flavobacterium) micromati derived from the abbreviation MICROMAT (MICROMAT project 'Biodiversity of Microbial Mats in Antarctica').
(2) When proposing arbitrary names or epithets, authors should aim at short, elegant, easily spelled and pronounced ones.

Note: with arbitrary genus names the gender must also be indicated!

The following list of informative and helpful literature is not an official part of Appendix 9.

\section{Further Reading}

Buchanan, R. E. (1994). Chemical terminology and microbiological nomenclature. Int J Syst Bacteriol 44, 566-590.

MacAdoo, T. O. (1993). Nomenclatural literacy. In Handbook of New Bacterial Systematics, pp. 339-358. Edited by M. Goodfellow \& A. G. O'Donnell. London: Academic Press.

Trüper, H. G. (1996). Help! Latin! How to avoid the most common mistakes while giving Latin names to newly discovered prokaryotes. Microbiologia 12, 473-475.

Trüper, H. G. (1999). How to name a prokaryote? Etymological considerations, proposals and practical advice in prokaryote nomenclature. FEMS Microbiol Rev 23, 231-249.

Trüper, H. G. (2001). Etymology in nomenclature of procaryotes. In Bergey's Manual of Systematic Bacteriology, 2nd edn, vol. 1, pp. 89-99. Edited by D. R. Boone, R. W. Castenholz \& G. M. Garrity. New York: Springer.

Trüper, H. G. (2004). The use of Neolatin in biological nomenclature. Neulateinisches Jahrb J Neo-Latin Lang Lit 6, 318-327.

Trüper, H. G. (2005). Is 'localimania' becoming a fashion for prokaryote taxonomists? Int J Syst Evol Microbiol 55, 1753.

Trüper, H. G. (2007). Neo-Latinists worldwide willing to help microbiologists. Int J Syst Evol Microbiol 57, 1164-1166. 